\title{
Sosyal Hizmet Mesleği Uygulama Standartlarına Genel Bakış: Amerika Birleşik Devletleri Örneği
}

\author{
DOI: 10.26466/opus.650547
}

\author{
$*$ \\ Ömer Faruk Cantekin* \\ * Dr. Öğr. Üyesi, Gazi Üniversitesi, Sağlık Bilimleri Fakültesi, Ankara/Türkiye \\ E-Posta: cantekin@gazi.edu.tr \\ ORCID: 0000-0001-5096-3233 \\ ** Arş. Gör., Gazi Üniversitesi, Sağllk Bilimleri Fakültesi, Ankara/Türkiye \\ E-Posta: aysenurpekasil@gazi.edu.tr \\ ORCID: $\underline{0000-0003-1864-0359}$
}

Öz

Bu çalışmanın amacı Amerika Birleşik Devletleri bağlamında sosyal hizmet mesleğinin yeterlilik ve uygulama standartlarının genel bir profilini çizmektir. Bu amaca yönelik olarak, en kapsamlı olan ve yaygin olarak referans verilen Ulusal Sosyal Hizmet Uzmanları Derneği (USHUD) tarafindan geliştirilen standartlar özet olarak açıklanmıştır. Sağlık hizmetleri, madde kullanım bozukluğu olan müracaatçılar, çocuk refahı alanı, ergenlere yönelik sosyal hizmet uygulamaları, klinik sosyal hizmet uygulamaları, yaşl yetişkine bakım veren aile üyelerine ilişkin uygulamalar ve okul sosyal hizmet uygulamaları başlıklarına yer verilmiştir. Sonuç olarak, sosyal hizmet uygulamalarının çeşitliliği göz önüne alındı̆̆ında tüm durumları kapsayan tek bir yeterlilik ve uygulama standard geliştirilememektedir. Sosyal hizmet uygulamalarının gerçekleştirildiği koşulların sürekli değişmekte olmasına rağmen, mevcut şartlarda kültürel yeterlilikler ve etik değerlerin dikkate alınmasıyla uzlaşılarak oluşturulmuş standartların açıkça belirtilmesi, sosyal hizmet bilgi temelinin nasıl kullanılacağına, etkili mesleki uygulamaların nasıl yapılabileceğine, hizmet sunumunda kamu kurum ve kuruluşları ile gönüllü kuruluşlar arasında nasıl bir işbirliği yapılacağına ve sunulan hizmetlerin nasıl değerlendirilebileceğine ışık tutacaktır. Son olarak, bu çalışmanın Türkiye bağlamında yapılacak standart geliştirme çalışmalarına da yardımcı olacă̆ı düşünülmektedir.

Anahtar Kelimeler: Amerika Birleşik Devletleri, sosyal hizmet mesleğinin yeterlilik ve uygulama standartları, uluslararası sosyal hizmet uzmanları derneği 


\title{
An Overview of the Social Work Practice Standards in the USA
}

\begin{abstract}
The aim of this study is to portray a general profile of the competency and practice standards of social work as a profession in the United States of America. To this end, being the most comprehensive and commonly referred ones, the standards developed by National Association of Social Workers (NASW) have been briefly explained. Healthcare services, clients with substance use disorders, child welfare, the practice of social work with adolescents, clinical social work practices, social work practice with family caregivers of older adults, and school social work practices. As a result, considering the variety of social work practices, it seems not possible to develop only one competency and practice standard good enough to cover all possible cases. Although the conditions of social work delivery are changing, to explicitly express the standards developed with a broad consensus considering the cultural competencies and ethical values in the current circumstances is thought to shed light on how the knowledge base of social work should be used, how effective professional practices should be implemented, what kind of collaboration could be possible between public and voluntary organizations in service delivery, and how the services provided could be evaluated. Finally, this study is expected to contribute to the standard development processes in social work in Turkey.
\end{abstract}

Keywords: United States of America, competency and practice standards of social work, national association of social workers 


\section{Giriş}

Amerika Birleşik Devletleri siyasal yönetim yapısı olarak eyalet sistemini benimsemiştir. Buna göre ulusal düzeydeki kuruluşlar ve eyaletlerde yer alan kuruluşlar farklı referans çerçeveleri kullanmış ve kimi noktalarda birbiriyle örtüşse de farklı yeterlilik ve uygulama standartları geliştirmişlerdir. $\mathrm{ABD}^{\prime}$ de ulusal düzeyde faaliyet gösteren önde gelen kurum Ulusal Sosyal Hizmet Uzmanları Derneği (USHUD) (National Association of Social Workers - NASW)'dir. Dernek, Washington merkezlidir ve standartlar konusunda en kapsamlı çalışmaları yürüttüğü söylenebilir.

Ulusal düzeyde USHUD tarafından geliştirilmiş standart, performans beklentileri ve göstergelerinden, sosyal hizmetin alt uygulama alanlarına yönelik (ergenlerle sosyal hizmet, madde bağımlılarıyla sosyal hizmet, okul sosyal hizmeti vb.) olarak geliştirilen yeterlik standartları vardır. Benzer şekilde Amerikan Ulusal Okul Sosyal Hizmeti Derneği (School Social Work Association of America - SSWAA) tarafından geliştirilmiş okul sosyal hizmeti uygulamalarına yönelik yeterlilik alanlarında standartlar mevcuttur. Diğer yandan üniversiteler, STK'lar ve eyaletlerde yer alan ilgili kurulların da ulusal standartların dışında özellikle sosyal hizmet eğitimine yönelik geliştirmiş olduğu standartlar bulunmaktadır. Bu çalışmada bunlardan en kapsamlı olan ve yaygın olarak referans verilen USHUD tarafından geliştirilen standartlar özet olarak değerlendirilmiştir.

\section{Sağlık Hizmetleri Bağlamında Sosyal Hizmet Uygulamaları Meslek Standartları}

ABD'de sosyal hizmet uzmanı Sosyal Hizmet Eğitimi Konseyi tarafından akredite edilmiş bir program ya da fakülte tarafindan verilen sosyal hizmet alanında lisans ya da yüksek lisans diplomasına sahip kişi olarak anlaşılmaktadir (NASW, 2016).

Bu bölümde yer alan 13 standart 2016 yılında USHUD tarafından sağlık hizmetleri bağlamında yürütülen sosyal hizmet uygulamaları için geliştirilmiştir. Sosyal hizmetin sağlik hizmetlerinde önemli bir yer tuttuğu belirtilmiş ve sosyal hizmet uzmanlarını önleyici halk sağlığı, birincil ve akut bakım, rehabilitasyon, uzun dönemli bakım gibi pek çok alanda faaliyet gösterdiğine dikkat çekilmiştir. Ayrıca, profesyonel sosyal hizmet uzmanlarının verdikleri 
hizmetin bireylerin iyilik hallerini etkileyen biyopsikososyal, tinsel ve çevresel konuları kapsadığı ifade edilmiştir (NASW, 2016). Görüldüğü gibi birey hem kendi özellikleri hem de çevre etkisiyle bir bütün olarak ele alınmaktadir.

Diğer yandan, standartların bazı temel ilkelere dayandığı ifade edilmiştir. $\mathrm{Bu}$ ilkeler danışanın kendi kaderini tayini (self-determination), kültürel yeterlik ve tüm insanların onurlu ve değerli olduğunun teyidi, ekolojik perspektif, güçlü yanlara vurgu, danışan-sosyal hizmet uzmanı ilişkisinin önemi, sosyal adalet, sosyal hizmet araştırmalarının önemi (NASW, 2016) olarak ifade edilmiştir.

Sağlık hizmetleri bağlamında yürütülen sosyal hizmet uygulamaları için geliştirilmiş olan standartlar sırasıyla şu şekildedir:

1. Etik ve Değerler: Sağlık hizmetlerinin verildiği ortamlarda çalışan sosyal hizmet uzmanları, etik kararların alınmasında rehber olarak USHUD Mesleki Etik Kurallarm (2008) kullanarak, sosyal hizmet mesleğinin etiğine ve değerlerine uyar ve bunları destekler.

2. Nitelikler: Sağlık hizmetlerinin verildiği ortamlarda çalışan sosyal hizmet uzmanları, Sosyal Hizmet Eğitimi Konseyi tarafından akredite edilmiş bir program ya da fakülte tarafından verilen sosyal hizmet alanında lisans ya da yüksek lisans diplomasına sahiptir, uygulama yaptığı eyaletin ya da bölgenin lisans ve sertifikasyon gereklerine uyar ve sağlık hizmetlerinin verildiği ortamlarda sosyal hizmet uygulamaları yapabilecek becerilere ve mesleki deneyime sahiptir.

3. Bilgi: Sağlık hizmetlerinin verildiği ortamlarda çalışan sosyal hizmet uzmanları, işlevsel güncel kuramsal bilgi ve kanıta dayalı uygulama bilgisini edinir, sürdürür ve bu bilgiyi sosyal hizmet uygulamasının kaliteli bir biçimde verilmesini sağlamak için kullanır. Bu bilgi ve beceriler fiziksel ve zihinsel/davranışsal sağlık, sağlık hizmetleri sistemine ilişkin konular, sağlık hizmeti verilen ortamlarda sosyal hizmet uzmanlarının rolleri- sorumlulukları ve araştırma- değerlendirme alanlarını kapsamaktadir.

4. Kültürel ve Dilsel Yeterlik: Sağlık hizmetlerinin verildiği ortamlarda çalışan sosyal hizmet uzmanları, Sosyal Hizmet Uygulamalarında Kültürel Yeterlik Göstergeleri ve Standartları'na (bir sonraki başlıkta ayrıntıları 
verilecektir) uygun olarak (NASW, 2015b) kültürel ve dilsel açıdan uygun bir biçimde hizmetlere erişimi sağlar ve kolaylaştırır. ABD toplumsal yapısı oldukça geniş bir çeşitlilik (ırk, etnik köken, sosyoekonomik durum, cinsel yönelim, din, yaş, aile durumları, dil vb.) göstermektedir. Bu nedenle, bu alandaki yeterlik sosyal hizmet uygulamalarının layıkıyla yapılabilmesi için ayrı bir önem taşımaktadır.

5. Tarama ve Değerlendirme: Sağlık hizmetlerinin verildiği ortamlarda çalışan sosyal hizmet uzmanları, kanıta dayalı bakım planları geliştirmek için kullanmak üzere bilgi toplayarak danışanları ve danışan destek sistemlerinin üyelerini uygun olduğu durumlarda tarama ve değerlendirme faaliyetlerinde kullanır. Bu bağlamda, biyopsikososyal ve tinsel değerlendirmede sosyal hizmet uygulamalarının temel süreçlerinden biridir. Ayrıca değerlendirme bir defaya mahsus bir faaliyet olmayıp sürekli yapılan bir uygulamadır.

6. Bakım Planlama ve Müdahale: Sağlık hizmetlerinin verildiği ortamlarda çalışan sosyal hizmet uzmanları, danışan ve aile merkezli bir bakım süreci sağlar ve danışanın iyi olma durumunu artıracak kanıta dayalı bakım planları geliştirir ve uygular. Yapılabilecek müdahaleler arasında bilişsel-davranışsal terapi, güdüleyici görüşme, kronik hastalıklarda özyönetim, psiko-eğitimsel hizmetler, kısa süreli terapi sayılabilir.

7. Savunuculuk: Sağlık hizmetlerinin verildiği ortamlarda çalışan sosyal hizmet uzmanları, özellikle marjinal, tıbbi açıdan karmaşık ya da dezavantajlı gruplara hizmet verilmesi, bakıma erişim ve çıktıların iyileştirilmesi amacıyla sistem düzeyinde değişimi destekler ve danışanların ve danışan destek sistemlerinin çıkar ve ihtiyaçlarını savunur. Sosyal hizmet uzmanı danışanın haklarını sağlık hizmetlerine erişimi kolaylaştırarak, hizmetlerin ulaşmasına engel olan noktaları tespit edip kaldırarak korur ve karmaşık sağlık sistemi ve sosyal sistem içinde danışanın kolay yön bulmasina yardimci olur.

8. Disiplinlerarası ve Örgütler Arası İşbirliği: Sağlık hizmetlerinin verildiği ortamlarda çalışan sosyal hizmet uzmanları, danışanlara ve danışan destek sistemlerine etkili hizmetlerin ulaşmasını sağlar ve bu hizmetleri destekleyip geliştirir ve sağlık hizmetleri personeli ve diğer meslektaşlar arasındaki işbirliğini destekler. 
9. Uygulamaların Değerlendirilmesi ve Kalite İyileştirme: Sağlık hizmetlerinin verildiği ortamlarda çalışan sosyal hizmet uzmanları, danışan sağlığının iyileştirilmesi ve iyi olma halinin artırılması için sürekli yapılan biçimsel uygulama değerlendirme sürecine katılır, hizmetlerin etkililiğini ve uygunluğunu değerlendirir ve uygulamaları güçlendirerek yeterlikleri artırır.

10. Kayıt Tutma ve Gizlilik: Sağlık hizmetlerinin verildiği ortamlarda çalışan sosyal hizmet uzmanları, danışana ait bilgilerin gizliliğini ve korunmasını sağlar ve danışanın değerlendirilmesi, yapılan müdahaleler ve çiktılarına ilişkin bilgileri zamanında kayıt altına alır. Kayıt tutma, sosyal hizmet uygulamasının, program değerlendirmesinin ve bakım planlama faaliyetinin temelini oluşturmaktadır. Sosyal hizmet uzmanlarının yerel, eyalet ve ulusal düzeylerdeki gizlilik kurallarına harfiyen uymaları beklenir.

11. İş Yükü̈ Sürdürülebilirliği: Sağlık hizmetlerinin verildiği ortamlarda çalışan sosyal hizmet uzmanları, sorumlulukları gereği sosyal hizmetlerin kaliteli ve etkin olarak sunulmasına imkan sağlayacak içerikte ve yoğunlukla iş yükü almayı destekler.

12. Mesleki Gelişim: Sağlık hizmetlerinin verildiği ortamlarda çalışan sosyal hizmet uzmanları, bağlı bulunduğu eyaletin ya da bölgenin lisans ve sertifikasyon gerekleri çerçevesinde ve Sürekli Mesleki Eğitim Standartları'na (NASW, 2003) uygun olarak kendi mesleki gelişimlerini sürdürme konusunda kişisel olarak sorumluluk üstlenir. Sosyal hizmet uzmanları kendi uygulama alanları çerçevesinde yeterliklerini sürdürebilmek için devamlı bir mesleki gelişim süreci içinde olmalıdır.

13. Denetim ve Liderlik: Sağlık hizmetlerinin verildiği ortamlarda çalışan sosyal hizmet uzmanları, kendi kurumları içerisindeki eğitsel, denetimsel, yönetsel ve araştırmaya ilişkin faaliyetlerde liderlik rolü üstlenir, sağlıklı bir sosyal hizmet işgücü oluşmasına katkı sağlamak için sosyal hizmet mesleği içinde yer alan diğer personele mentörlük yapar. Sağlık hizmetleri bağlamındaki sosyal hizmet denetiminin amacı denetlenen uzmanın mesleki bilgi ve becerilerini geliştirmek ve danışanlara ve ailelere kaliteli hizmet götürebilme yeterliğini artırmaktır. Denetim mesleki gelişimi kolaylaştırır ve klinik sonuçların iyileşmesine neden olur (NASW, 2016). 


\section{Madde Kullanım Bozukluğu Olan Danışanlara Yönelik Sosyal Hizmet Uygulamaları Standartlan}

Bu bölümde yer alan 12 Standard 2013 yılında USHUD tarafından Madde Kullanım Bozukluğu Olan Danışanlara Yönelik Sosyal Hizmet Uygulamaları için geliştirilmiştir (NASW, 2013).

1. Etik ve Değerler: Madde kullanım bozukluğu olan danışanlarla çalışan sosyal hizmet uzmanları, sosyal hizmet mesleğinin etiğine ve değerlerine bağlıdır ve etik kararların alınmasında rehber olarak USHUD Mesleki Etik Kurallarını (2008) kullanır. Madde kullanım bozukluğu olan danışanlarla yapılan sosyal hizmet uygulamalarının kendine özgü yönlerini, danışanların ve ailelilerinin ihtiyaçlarını bilir.

2. Nitelikler: Madde kullanım bozukluğu olan danışanlarla çalışan sosyal hizmet uzmanları, USHUD ve ilgili eyalet ya da federal yasalarca belirlenen mesleki uygulama koşullarını sağlar ve madde kullanım bozukluğu olan danışanlarla yapılan mesleki uygulamalara ilişkin sosyal hizmet mesleğinin temel bilgi ve yaklaşımlarıyla donanıktır.

3. Değerlendirme: Madde kullanım bozukluğu olan danışanlarla çalışan sosyal hizmet uzmanları, madde kullanım bozukluğu olan danışanlara uygun teşhis ve tedavi planlarını sağlamak için danışanlarıyla ilgili sürekli değerlendirme yapar.

4. Müdahale: Madde kullanım bozukluğu olan danışanlarla çalışan sosyal hizmet uzmanları, yaptıkları müdahalelerde değerlendirme ve kanıta dayalı uygulama temelli bilgilere sahiptir ve bu bilgileri uygulamalarında kullanir.

5. Karar Verme ve Uygulamanın Değerlendirilmesi: Madde kullanım bozukluğu olan danışanlarla çalışan sosyal hizmet uzmanları, danışan hizmetlerini geliştirmek ve genişletmek için kendi yaptıkları uygulamaları düzenli olarak değerlendirir ve verileri hizmet sunumuna rehberlik etmek için kullanır.

6. Kayıt Tutma: Madde kullanım bozukluğu olan danışanlarla çalışan sosyal hizmet uzmanları, meslek etiği, yerel, eyalet ve federal düzeydeki talimatlar doğrultusunda uygun ve doğru verilerin ve sosyal hizmetlerin planlanması, uygulanması ve değerlendirilmesi ile ilgili belgelerin kaydinı tutar. 
7. İş Yükü Yönetimi: Sosyal hizmet uzmanları, madde kullanım bozukluğu olan danışanlara hizmet verirken kendi sorumluluklarını yerine getirmek ve kendi rollerini netleştirmek için iş yüklerini organize eder.

8. Mesleki Gelişim: Sosyal hizmet uzmanları, madde kullanım bozukluğu olan danışanlara ve ailelerine en yeni, en faydalı ve kültürel açıdan en uygun hizmetleri sunabilmek için bilgi ve becerilerini sürekli iyileştirme çabası içindedir.

9. Kültürel Yeterlik: Sosyal hizmet uzmanları, bütün danışanlara ve ailelerine kültürel anlayış ve yeterlik çerçevesinde hizmet götürülmesini sağlar.

10. Disiplinlerarası Liderlik ve İşbirliği: Sosyal hizmet uzmanları, olumlu tedavi ortamlarının geliştirilmesinde, diğer profesyonellerin denetiminde, yönetimsel istikametin belirlenmesinde, madde kullanım bozukluğu ile ilgili araştırmalarda ve tedavilerin geliştirilmesinde liderlik yapar.

11. Savunuculuk: Sosyal hizmet uzmanları, madde kullanım bozukluğu olan danışanların ve ailelerinin uygun olan hizmetlere eşitliğe uygun olarak zamanında erişmesini sağlamak adına savunuculuk rolü üstlenir.

12. İşbirliği: Sosyal hizmet uzmanları, madde kullanım bozukluğu olan danışanlara ve ailelerine verilecek etkin hizmetleri desteklemek, iyileştirmek ve sunmak için disiplinlerarası ve kurumlar arası işbirliğine destek verir (NASW, 2013).

\section{Çocuk Refahı Alanındaki Sosyal Hizmet Uygulamaları Standartları}

Bu bölümde yer alan 14 Standard 2013 yılında USHUD tarafından Çocuk Refahı Alanındaki Sosyal Hizmet Uygulamaları için geliştirilmiştir (NASW, 2013).

1. Etik ve Değerler: Çocuk refahı alanında çalışan sosyal hizmet uzmanları, sosyal hizmet mesleğinin etiğine ve değerlerine bağlllık gösterir ve etik kararların alınmasında rehber olarak USHUD Mesleki Etik Kuralların kullanır. Çocuk refahına yönelik sosyal hizmet uygulamalarının kendine özgü yönlerini bilir. 
2. Nitelikler, Bilgi ve Uygulama Şartları: Çocuk refahı alanında çalışan sosyal hizmet uzmanlarl, akredite olmuş bir sosyal hizmet fakültesinden al1nan lisans ya da yüksek lisans diplomasına sahiptir. Bu alanda çalışan sosyal hizmet uzmanları çocuk refahı alanındaki mevcut kuramsal ve uygulamaya ilişkin yeterli bilgiye sahiptir. Eyalet ve federal düzeylerde çocuk refahyyla ilgili yasalara ilişkin genel bilgi sahibidir.

3. Mesleki Gelişim: Çocuk refahı alanında çalışan sosyal hizmet uzmanları, çocuk refahı alanına giren çocuklara, gençlere ve ailelerine en yeni, en faydalı ve kültürel açıdan en uygun hizmetleri sunabilmek için bilgi ve becerilerini sürekli olarak oluşturma çabası içindedir.

4. Savunuculuk: Çocuk refahı alanında çalışan sosyal hizmet uzmanları, çocuklara, gençlere ve ailelerine yönelik hizmetleri iyileştirecek sistem reformlarını ve kaynakları savunur ve destekler.

5. İşbirliği: Çocuk refahı alanında çalışan sosyal hizmet uzmanları, çocuklara, gençlere ve ailelerine yönelik etkin hizmetleri desteklemek, iyileştirmek ve sunmak için disiplinlerarası ve kurumlar arası işbirliğine destek verir.

6. Kayıt Tutma ve Danışana Ait Bilgilerin Gizliliği: Çocuk refahı alanında çalışan sosyal hizmet uzmanları, danışanlara ait bilgilerin gizliliğini koruyacak uygun önlemleri alır.

7. Kültürel Yeterlik: Çocuk refahı alanında çalışan sosyal hizmet uzmanları, ailelere kültürel anlayış ve yeterlik çerçevesinde hizmet götürülmesini sağlar.

8. Değerlendirme: Çocuk refahı alanında çalışan sosyal hizmet uzmanları, önemli bilgileri toplamak amaciyla çocukların, gençlerin ve aile sisteminin başlangıçta kapsamlı bir değerlendirmesini yapar. Sosyal hizmet uzmanı aynı zamanda çocuk refahı hizmetlerine yönelik planların geliştirilmesi ve düzeltilmesi için sürekli değerlendirme yapar.

9. Müdahale: Çocuk refahı alanında çalışan sosyal hizmet uzmanları, kanıta dayalı uygulamalar yoluyla çocukların güvenliğini ve iyi olmalarını sağlamaya çalışır.

10. Ailenin Sürece Dahil Edilmesi: Çocuk refahı alanında çalışan sosyal hizmet uzmanları, çekirdek aile üyelerini ya da geniş aile üyelerini paydaş olarak değerlendirir ve yeniden birleşmenin yer aldığı müdahale sürecine dahil eder. 
11. Gençlerin Sürece Dahil Edilmesi: Çocuk refahı alanında çalışan sosyal hizmet uzmanları, yaşça büyük gençleri ev dişı bakım sürecindelerken ve koruyucu aile bakımı sürecinden çıkmak üzere olduklarında kendi ihtiyaçlarıla ilgilenmeye yönlendirir.

12. Kalıcılık Planlama: Çocuk refahı alanında çalışan sosyal hizmet uzmanları, çocuklar ve gençler kendi evlerinde güven içinde kalamaz duruma geldiklerinde onların ev dışı bakım hizmetlerinden yararlanmalarını sağlar. Sosyal hizmet uzmanları, mümkün olan en kısa zamanda ya da çocukları bir başka aile yanına kalıcı olarak yerleştirir yerleştirmez kalıcılık planlama çabalarını çocukların eve dönmesine yoğunlaştırır.

13. Denetim: Çocuk refahı alanında denetmen olarak çalışan sosyal hizmet uzmanları, sosyal hizmet uzmanlarının becerilerini geliştirebilecekleri olumlu çalışma ortamının oluşturulmasını ve sürdürülmesini teşvik eder, güvenli ve olumlu bir iş ortamı oluşturur, sosyal hizmet uzmanlarına kaliteli denetim hizmeti verir ve danışanlara nitelikli hizmetlerin ulaşmasını sağlar.

14. Yönetim: Çocuk refahı alanında yönetici olarak çalışan sosyal hizmet uzmanları, mesleki sorumluluklarını yerine getirirken çalışanların faaliyetleri konusunda yasal korumayı ve yeni teknolojilerin uygun biçimde kullanımin, yeterli denetim hizmeti verilmesini ve makul düzeyde vaka yükü ve iş yükü dağıtımını destekleyen bir örgüt kültürünü savunur (NASW, 2013).

\section{Ergenlere Yönelik Sosyal Hizmet Uygulamaları Standartları}

Bu bölümde yer alan 11 Standard 2003 yılında USHUD tarafindan Ergenlere Yönelik Sosyal Hizmet Uygulamaları için geliştirilmiştir (NASW, 2003).

1. Ergen Gelişimi Bilgisi: Sosyal hizmet uzmanları, ergen gelişimine ilişkin bilgi ve anlayış sahibidir.

2. Değerlendirme: Sosyal hizmet uzmanları, ergenlere ve ailelerine hizmet veren toplum temelli kaynaklara ve sosyal kurumlara erişim de dahil olmak üzere ergenlere verilen hizmetleri değerlendirme yeteneğine sahiptir ve bu konuda gerekli kaynakların geliştirilmesini savunur.

3. Aile Dinamikleri Bilgisi: Sosyal hizmet uzmanları, aile dinamikleri ve sistem kuramına ilişkin bilgi ve anlayış sahibidir. 
4. Kültürel Yeterlik: Sosyal hizmet uzmanları, hizmet verirken kültürel yeterliğe sahip olduğunu gösterir.

5. Ergenlerin Güçlendirilmesi: Sosyal hizmet uzmanları, ergenlerin kendilerini güçlendirmelerine yardımcı olur.

6. Ergen İhtiyaçlarının Anlaşılması: Sosyal hizmet uzmanları, ergenlerin ihtiyaçlarına yönelik ve ergenlerin ihtiyaçlarının karşılanması için uzmanlar ve kurumlar arası işbirliği ve kaynak kullanımına yönelik bir anlayışın geliştirilmesi gerektiğini savunur.

7. Çok Disiplinli Vaka Konsültasyonu: Sosyal hizmet uzmanları, ergenlere hizmet sunan kurumlarda yapılan çok disiplinli vaka konsültasyonu uygulamalarında yer alır.

8. Gizlilik: Sosyal hizmet uzmanları, gençlerle olan ilişkilerinde gizlilik ve kişiye özel durumlara yönelik yeterli koruyucu önlemi alır.

9. Çalışma Ortamı: Sosyal hizmet uzmanları, kendi mesleki gelişimlerinin, kurum politikalarının, danışanlarla yapılan uygulamaların ve çalışma ortamının niteliğine ve geliştirilmesine katkı sağlamada etkin rol üstlenir.

10. Savunuculuk: Gençlere hizmet veren kurumlarda çalışan sosyal hizmet yöneticileri, tüm çalışanlar için uygun çalışma koşullarını ve sosyal hizmet uzmanlarının gençlerin ihtiyaçlarını karşılayabilmeleri için yeterli kaynakların ve politika değişikliklerinin yapılmasını ve gençlerin ihtiyaçlarına yönelik ileri düzeyde bir anlayışın geliştirilmesi gerektiğini savunur.

11. Etkin Uygulamalar için Politika: Gençlere hizmet veren kurumlarda çalışan sosyal hizmet yöneticileri, ergenlere yönelik etkin sosyal hizmet uygulamalarının yapılabilmesi için gereken ilkeleri, süreçleri, politikaları ve ortamı oluşturur (NASW, 2003).

\section{Klinik Sosyal Hizmet Standartları}

Bu bölümde yer alan 12 Standard 2005 yılında USHUD tarafından Klinik Sosyal Hizmet Uygulamaları için geliştirilmiştir (NASW, 2005).

1. Etik ve Değerler: Klinik sosyal hizmet uzmanları, sosyal hizmet mesleğinin etiğine ve değerlerine bağlıdır ve etik kararların alınmasında rehber olarak USHUD Mesleki Etik Kurallarını kullanır. 
2. Uzmanlık Gerektiren Uygulama Becerileri ve Müdahale: Klinik sosyal hizmet uzmanları, bireylere, ailelere ve gruplara yönelik etkin klinik müdahale yapabilecek uzmanlık bilgi ve becerisine sahiptir.

3. Yönlendirme/Sevk: Klinik sosyal hizmet uzmanları, kamu hizmeti konusunda bilgi sahibidir ve gerektiğinde uygun sevk işlemini yapar.

4. Ulaşılabilirlik: Klinik sosyal hizmet uzmanları, acil ve acil olmayan durumlarda danışanlar tarafından ulaşılabilir durumdadır.

5. Gizlilik: Klinik sosyal hizmet uzmanları, tedavi sürecindeki ilişkinin kişiye özel doğasını korumak için yeterli önlemleri alır.

6. Denetim ve Konsültasyon: Klinik sosyal hizmet uzmanları, mesleki denetimden ve / veya konsültasyondan yararlanırlar. Klinik sosyal hizmet uzmanları, mesleğe başladıkları ilk 5 yıl içerisinde kendi klinik ortamlarında erişebilecekleri bir mesleki sosyal hizmet denetim hizmetinin verilmesini sağlar. Klinik sosyal hizmet denetçisinin bulunmadığı durumlarda diğer disiplinlere mensup nitelikli uzmanlardan vaka konsültasyonu alınabilir.

7. Mesleki Ortam ve İşleyiş: Klinik sosyal hizmet uzmanları, mesleklerine uygun görevleri işlemleri yerine getirir. Klinik sosyal hizmet sağlayan kurumlar ve özel / bağımsız çalışan klinik sosyal hizmet uzmanları verdiği hizmetin niteliğini ve izlenen yolu (danışanın hakları, ücretlendirme vb.) açıklayan yazılı politikaları geliştirir ve uygular. Bu politikalar tedaviye başlamadan önce her bir danışan tarafından gözden geçirilir.

8. Dokümantasyon: Danışanlara yönelik veya danışanlar adına yürütülen hizmetlerin dokümantasyonu danışan dosyasında ya da hizmet kayıtlarında tutulur.

9. Bă̆ımsız Uygulama: Klinik sosyal hizmet uzmanları, bağımsız çalışma hakkına sahiptir.

10. Kültürel Yeterlik: Klinik sosyal hizmet uzmanları, USHUD Sosyal Hizmet Uygulamalarmda Kültürel yeterlik Standartları'na uygun olarak, hizmet verirken kültürel yeterliğe sahip olduğunu gösterir.

11. Mesleki Gelişim: Klinik sosyal hizmet uzmanları, bağlı bulundukları eyaletin kurallarına ve USHUD Sürekli Mesleki Gelişim Standartları'na uygun olarak, mesleki gelişimlerinin sorumluluğunu üstlenir. 
12. Teknoloji: Elektronik posta yoluyla iletişim kurma ve eğitim, işbirliği ve kaynaklara erişme gibi amaçlarla internette bilgi arama etkin ve verimli bir klinik sosyal hizmet uygulaması için çok önem arz ettiği için, klinik sosyal hizmet uzmanlarının bilgisayar ve internet teknolojilerine erişimi vardır (NASW, 2005).

\section{Yaşlı Yetişkinlere Bakan Aile Üyelerine Yönelik Sosyal Hizmet Standartları}

Bu bölümde yer alan 12 Standard 2010 yılında USHUD tarafından Yaşlı Yetişkinlere Bakan Aile Üyelerine Yönelik Sosyal Hizmet Uygulamaları için geliştirilmiştir. Standartlara geçmeden önce bazı kavramların açıklanması standartların doğru anlaşılması açısından önemlidir. İlk olarak aile bakımı sağlayan kişi (Family caregiver), yaşlı bir yetişkine bakma sorumluluğunu üstlenen kişinin kan bağıyla bağlı olduğu ailesi, geniş aile çevresi, birlikte yaşayanlar, arkadaşlar ya da diğer bireylerden oluşabilmektedir. Bir diğer kavram ise aile bakımıdır. Yaşlı yetişkinlerin hayat kalitesini sürdürmesine yardımcı olabilecek etkinliklerin bütünü bu kavram çerçevesinde değerlendirilmektedir. Faaliyetler arasında duygusal, sosyal ve tinsel destek sağlama, sağlık, mali işler gibi alanlarda planlama yapmaya destek olma, banyo yapma, giyinme ve yürüme gibi bazı temel fiziksel işlerde destek sağlama, ev işlerine yardımcı olma sayılabilir (NASW, 2010).

1. Etik ve Değerler: Yaşlı yetişkinlere bakan aile üyelerine hizmet sunan sosyal hizmet uzmanları, sosyal hizmet mesleğinin etiğine ve değerlerine bağlıdır ve etik kararların alınmasında rehber olarak USHUD Mesleki Etik Kuralların kullanır.

2. Nitelikler: Yaşlı yetişkinlere bakan aile üyelerine hizmet sunan sosyal hizmet uzmanları, Sosyal Hizmet Eğitimi Konseyi tarafından akredite edilmiş bir program ya da fakülte tarafından verilen sosyal hizmet alanında diploma sahibidir, bağlı bulunduğu eyaletin lisans ve sertifikasyon gereklerini yerine getirir. Yaşlanma ve aile bakımı alanlarında bilgi, beceri ve deneyim sahibidir.

3. Bilgi: Sosyal hizmet uzmanları, yaşlanma ve aile bakımı alanlarıyla ilgili değerlendirme ve kanıta dayalı araştırma yöntemlerini, politika, sosyal 
ve tarihsel bağlamı, mevcut kuram ve uygulamaları bilir, bu konularda yeterli bilgi edinir ve bu bilgileri uygulamayla bütünleştirir.

4. Kültürel ve Dilsel Yeterlik: Sosyal hizmet uzmanları, Sosyal Hizmet Uygulamalarında Kültürel Yeterlik Göstergeleri ve Standartları USHUD Erişi Göstergeleri'ne (NASW, 2007) uygun olarak, yaşlı yetişkinlere bakan aile üyelerinin kültürel ve dilsel açıdan uygun hizmetlere ulaşmalarını sağlar ve kolaylaştırır.

5. Değerlendirme: Sosyal hizmet uzmanları, hizmet ve bakıma ilişkin planların geliştirilmesi ve düzeltilmesi için kapsamlı bilgi toplayarak yaşlı yetişkinlere bakan aile üyelerine yönelik sürekli değerlendirme yapar.

6. Hizmetlerin Planlanması, Sunulması ve İzlenmesi: Sosyal hizmet uzmanları, yaşlılara bakanların iyi olma durumlarına katkı sağlayan ve güçlü yanlarını destekleyen bireyselleştirilmiş hizmetlerin planlanması, sunulması ve izlenmesi faaliyetlerinde yaşlı yetişkinlere bakan aile üyeleriyle işbirliği yapar. Bakım planları değerlendirmeye dayalıdır ve planların ölçülebilir amaçları vardır.

7. Savunuculuk: Sosyal hizmet uzmanları, yaşlı yetişkinlere bakan aile üyelerinin haklarını, kararlarını ve ihtiyaçlarını savunur. Yaşlı yetişkinlere bakan aile üyelerinin biyopsikososyal ihtiyaçlarını karşılamaları için onlara kaynaklara eşit erişim imkanı sağlayacak sosyal ve politik adımları atar.

8. İşbirliği: Sosyal hizmet uzmanları, yaşlı yetişkinlere bakan aile üyelerine yönelik hizmetleri geliştirmek, desteklemek ve iyileştirmek için disiplinlerarası ve kurumlar arası işbirliğine destek verir.

9. Uygulama, Değerlendirme ve Geliştirme: Yaşlı yetişkinlere bakan aile üyelerine hizmet veren sosyal hizmet uzmanları, aile üyelerinin iyi olma durumlarını en yüksek düzeye çıarmak için yürüttükleri uygulamaları sürekli ve biçimsel olarak değerlendirir, hizmetlerin kalitesini ve uygunluğunu denetler, uygulamayı iyileştirir ve yeterlik sağlar.

10. Dokümantasyon: Sosyal hizmet uzmanları, yaşlı yetişkinlere bakan aile üyeleriyle yaptığı bütün uygulamaları uygun danışan kayıtları içinde belgeler. Sosyal hizmet dokümantasyonu yazılı olarak ya da elektronik ortamda kaydedilebilir ve işveren taleplerine, yönetmelik ve yasalara uygun olarak tamamlanır, muhafaza edilir ve açılır. 
11. İş Yükü: Sosyal hizmet uzmanları, yaşlı yetişkinlere bakan aile üyelerine etkin ve yüksek kalitede hizmet sunabilecek nitelikte bir iş yükü verilmesini savunur. Sosyal hizmet personelinin büyüklügü hem organizasyonun kapsamı ve karmaşık yapısını hem de hizmet götürülen nüfusun sayısını ve doğasını temsil eder.

12. Mesleki Gelişim ve Yeterlik: Yaşlı yetişkinlere bakan aile üyeleri ile çalışan ya da onlar adına uygulama yapan sosyal hizmet uzmanları, bağlı bulundukları eyaletin kurallarına ve USHUD Sürekli Mesleki Gelişim Standartları'na ve USHUD Mesleki Etik Kurallarma (2008) uygun olarak, mesleki gelişimlerinin ve yeterliklerinin kişisel sorumluluğunu üstlenir (NASW, 2010).

\section{Okul Sosyal Hizmeti Standartları}

Bu bölümde yer alan 11 Standard 2012 yılında USHUD tarafından Okul Sosyal Hizmeti Uygulamaları için geliştirilmiştir (NASW, 2012).

1. Etik ve Değerler: Okul sosyal hizmeti uzmanları, sosyal hizmet mesleğinin etiğine ve değerlerine bağllık gösterir ve etik kararların alınmasında rehber olarak NASWMesleki Etik Kurallarını kullanır. Okul sosyal hizmeti uygulamalarının ve hizmet verdikleri grupların, ailelerin ve öğrencilerin ihtiyaçlarının kendine özgü yönlerini bilir.

2. Nitelikler: Okul sosyal hizmeti uzmanlarl, NASW tarafindan ve sosyal hizmet uzmanının bağlı bulunduğu eyaletin eğitim kurulu tarafından belirlenen mesleki uygulama koşulların karşılar ve yerel eğitim sistemiyle ilgili bilgi ve anlayışın yanı sıra sosyal hizmet mesleğine özgü bilgilere ve anlayışa sahiptir.

3. Değerlendirme: Okul sosyal hizmeti uzmanları, öğrencilerin sosyal, duygusal, davranışsal ve akademik çıktılarını iyileştirmek amacıyla, bireylere, ailelere ve sistemlere / örgütlere (sınıf, okul, mahalle, semt, eyalet) yönelik değerlendirmeler yapar.

4. Müdahale: Okul sosyal hizmeti uzmanları, yaptıkları müdahalelerde kanita dayalı uygulamaları bilir ve uygular.

5. Karar Verme ve Uygulamalarn Değerlendirilmesi: Okul sosyal hizmeti uzmanları verileri, verilen hizmetleri genişletmek ve iyileştirmek için 
kendi uygulamalarını değerlendirmek ve hizmet sunumunu yönlendirmek amaciyla kullanir.

6. Kayıt Tutma: Okul sosyal hizmeti uzmanları, okul sosyal hizmeti uygulamalarının planlanması, gerçekleştirilmesi ve değerlendirilmesi ile ilgili doğru kayıt ve verileri muhafaza eder.

7. İş Yükü Yönetimi: Okul sosyal hizmeti uzmanları, çalıştıkları okul ya da bölgenin eğitimsel misyonu çerçevesinde kendi kritik rollerini netleştirmek ve sorumluluklarını yerine getirebilmek için iş yüklerini organize eder.

8. Mesleki Gelişim: Okul sosyal hizmeti uzmanları, öğrencilere ve ailelerine en güncel, en yararlı ve kültürel açıdan en uygun hizmetleri sunabilmek için bilgi ve becerilerini sürekli olarak geliştirmeye çalışır.

9. Kültürel Yeterlik: Okul sosyal hizmeti uzmanları, öğrencilerin ve ailelerinin çok kültürlülük anlayışı ve yeterliği çerçevesinde hizmet almalarını sağlar.

10. Disiplinlerarası Liderlik ve İşbirliği: Okul sosyal hizmeti uzmanlanı, olumlu bir okul ikliminin geliştirilmesine liderlik eder ve verilen hizmetlerin etkililiğini ve erişilebilirliğini artırmak için okul yönetimiyle, okul personeliyle, aile üyeleriyle ve uygun toplum uzmanlarıyla işbirliği yapar.

11. Savunuculuk: Okul sosyal hizmeti uzmanları, akademik gelişimlerini sürdürebilmeleri için öğrencilerin eğitim olanaklarına ve hizmetlere eşit ölçüde erişebilmelerini sağlamak için savunuculuk rolü üstlenir (NASW, 2012).

\section{Sosyal Hizmet Uygulamalarında Kültürel Yeterlik Göstergeleri ve Standartları}

Bu bölümde yer alan 10 Kültürel Yeterlik Göstergesi ve Standardı 2015 yılında NASW tarafından sosyal hizmet uzmanlarına yönelik olarak geliştirilmiştir (NASW, 2015).

1. Etik ve Değerler: Sosyal hizmet uzmanları, USHUD Mesleki Etik Kurallarının (2008) belirttiği değerlere, etiğe ve standartlara uygun olarak faaliyet gösterir. Kültürel yeterlik, özfarkındalık, kültürel alçak gönüllülük ve 
kültürün etkin sosyal hizmet uygulamaları için merkezi konumunu anlamayı ve benimsemeyi gerektirir.

2. Kendini Tanıma: Sosyal hizmet uzmanları, kendilerinin ve diğer bireylerin kültürel kimliklerini takdir ettiğini gösterir. Aynı zamanda sosyal hizmet uzmanları kendi güçlerinin ve imtiyazlı durumlarının farkında olmalı ve danışanlar adına ve danışanlarla yaptıkları çalışmalarda bu gücün ve imtiyazın etkisini bilmelidir. Diğer yandan sosyal hizmet uzmanları, sosyal hizmetin tüm uygulama alanlarında imtiyaz ve gücün dinamiklerine karşı hassasiyet göstermeli ve kültürel alçak gönüllüğe sahip olmalıdır.

3. Kültürler Arası Bilgi: Sosyal hizmet uzmanları, aşağıdaki konularla sınurlı olmamak kaydıyla ve fakat bu konuları kapsayan uzmanlık bilgisi ve anlayışına sahip olmalı ve bu anlayışı sürekli geliştirmelidir. Söz konusu konular tarih, gelenekler, değerler, aile sistemleri, rrk ve etnisite gibi sanatsal ifadeler, göçmenlik ve göçmen statüsü, kabile gruplar, din ve tinsellik, cinsel eğilim, cinsiyet kimliği ve ifadesi, toplumsal sınıf, çeşitli kültürel grupların zihinsel ya da fiziksel yeteneklerinden oluşmaktadır.

4. Kültürler Arası Beceriler: Sosyal hizmet uzmanları, kültürün araştırma, politika ve uygulama alanlarındaki önemine saygı duyduğunu ve bu önemi anladığını gösteren ve geniş bir dağılım gösteren beceri ve teknikleri (mikro, mezzo ve makro) kullanir.

5. Hizmet Sunumu: Sosyal hizmet uzmanları, hizmetlerin, kaynak ve kurumların kullanımıyla ilgili bilgi ve beceri sahibidir ve çok kültürlü toplumlara hizmet vermeye hazırdır. Sosyal hizmet uzmanları, hem biçimsel hem de biçimsel olmayan sosyal ağlarda kültürel açıdan uygun sevk işlemlerini yapabilir ve hizmet alanlarında özel kültürel grupları etkileyen boşlukları bilir ve bunlarla ilgili çalışma yapar.

6. Güçlendirme ve Savunuculuk: Sosyal hizmet uzmanları, sosyal sistemlerin, politikaların, uygulama ve programların çok kültürlü danışan grupları üzerindeki etkisinin farkındadır ve uygun olduğu durumlarda çok kültürlü danışanlar ya da çok kültürlü gruplar adına, onlarla birlikte, onlar için savunuculuk yapar. Aynı zamanda ezilen ve marjinal grupları savunan ve bu grupları güçlendiren politika ve uygulamaların geliştirilmesinde ve hayata geçirilmesinde de yer alır. 
7. İşgücü Çeşitliliği: Sosyal hizmet uzmanları, sosyal hizmet mesleği bünyesinde çeşitliliği sağlamak adına yapılacak işe alımları, ücretle görevlendirmeleri ve bireyleri işte tutma uygulamalarını destekler ve savunur.

8. Mesleki Eğitim: Sosyal hizmet uzmanları, sosyal hizmet mesleği bünyesinde kültürel yeterliği artıracak mesleki eğitim ve geliştirme programları geliştirir, destekler ve bu programlara katılır. Sosyal hizmet uzmanları, kültürel yeterliği hayat boyu öğrenmenin merkezine oturtmalıdır.

9. Dil ve İletişim: Sosyal hizmet uzmanları, sınırlı İngilizce dil yeterliğine sahip olan kişiler ya da okuryazarlık becerisi çok düşük olan kişiler, görme engelli ya da çok az görebilen kişiler, işitme engelli ya da çok az işitebilen kişiler ve diğer engelliler de dâhil olmak üzere bütün kültürel gruplardan gelen danışanlarla etkin bir iletişim kurar bu iletişimi destekler.

10. Kültürel Yeterliğin Artırılmasına Yönelik Liderlik: Sosyal hizmet uzmanları, kurumsal ve grup bağlamında çok kültürlü gruplarla etkin çalışma yürütebilecek liderlik becerilerine sahip değişim ajanlarıdır. Sosyal hizmet uzmanları, kendi kurumları bünyesinde ve ötesinde kültürel yeterliğin artırılmasında sorumluluk alır, yapısal ve kurumsal baskılara karşı koymada yardımcı olur, çeşitli ve kapsayıcı kurum ve cemiyetlerin oluşturulmasında ve sürdürülmesinde yer alır (NASW, 2015).

\section{USHUD Mesleki Etik Kuralları}

USHUD tarafindan geliştirilen sosyal hizmet standartlarının tamamında yine USHUD tarafından 2008 yılında geliştirilen Mesleki Etik Kurallarına atıf yapılmakta ve genellikle standartlardan ilki "etik ve değerler" olarak ifade edilmektedir. Bu nedenle, bu bölümde okuyucuya genel bir fikir vermek amacryla Mesleki Etik Kuralları özetlenmiştir.

Sosyal Hizmet mesleğinin misyonu bir dizi temel değere dayanmaktadır. Sosyal hizmet çalışanları sosyal hizmet tarihi boyunca bu temel değerleri benimsemiş ve bu değerler sosyal hizmetin kendine özgü amaç ve bakış açısının temelini oluşturmuştur. Hizmet, sosyal adalet bireyin değeri ve onuru, insan ilişkilerinin önemi, dürüstlük ve yeterlik temel değerleri oluşturmaktadır.

Mesleki etik kurallarının temel amaçları; 
1. Etik kurallar, sosyal hizmetin misyonunun dayandığı temel değerleri tanımlamaktadır.

2. Etik kurallar, mesleğin temel değerlerini yansıtan geniş kapsamlı etik ilkeleri özetlemekte ve sosyal hizmet uygulamalarının yönlendirilmesinde kullanılması gereken bir dizi özel etik standart sunmaktadır.

3. Etik kurallar, sosyal hizmet uzmanlarının, mesleki zorunlulukların çatışması halinde ya da etik açıdan belirsizliklerin ortaya çıkması durumunda ilgili düşünceleri tanımlayabilmelerine yardımcı olmak amacıyla tasarlanmıştır.

4. Etik kurallar, toplumun sosyal hizmet mesleğini hesap verilebilirliği olan bir meslek olarak kabul etmesini sağlayacak etik standartlar sunmaktadır.

5. Etik kurallar, alana yeni katılan uygulayıcıların etik standartları, etik ilkeleri, sosyal hizmetin misyonunu ve değerlerini benimsemelerini sağlar.

6. Etik kurallar, sosyal hizmet uzmanlarının etik dişı davranış gösterip göstermediğini tespit etmek için sosyal hizmet uzmanları tarafından kullanılabilecek standartları açıkça belirtmektedir.

Etik standartlar temelde altı başlık altında toplanmaktadır.

a) Sosyal Hizmet Uzmanını Danışanlara Karşı Etik Sorumlulukları: Danışana bağlılık, danışanın özerkliği, bilgilendirilmiş rıza, yeterlik, kültürel yeterlik ve sosyal çeşitlilik, çıkar çatışması, gizlilik, kayıtlara erişim, cinsel ilişki, fiziksel temas, cinsel taciz, aşağılayıcı dil kullanımı, ücretlendirme, kendi başına karar verme yetisi olmayan dantşanlar, hizmetlerin aksaması, hizmetlerin sonlandırılması başlıkları altında yer alan bir dizi standarttan oluşmaktadır.

b) Sosyal Hizmet Uzmanını Meslektaşlarına Karşı Etik Sorumluluklarn: Saygı, gizlilik, disiplinlerarası işbirliği, meslektaşların içinde olduğu anlaşmazlıklar, konsültasyon, hizmetlere yönlendirme, cinsel ilişki, cinsel taciz, meslektaşın kişisel sorunları, meslektaş yetersizliği, meslektaşlar tarafından etik dışı davranılması başlıkları altında yer alan bir dizi standarttan oluşmaktadır. 
c) Sosyal Hizmet Uzmaninin Uyulama Ortamindaki Etik Sorumluluklarn: Denetim ve konsültasyon, eğitim ve geliştirme, performans değerlendirme, danışan kayıtları, faturalandırma, danışan aktarımı, yönetim, sürekli eğitim ve personel geliştirme, işverene bağlllık, işçi-işveren anlaşmazlıkları başlıkları altında yer alan bir dizi standarttan oluşmaktadır.

d) Sosyal Hizmet Uzmaninn Bir Profesyonel Olarak Etik Sorumluluklarn: Yeterlik, ayrımcilık, özel yaşam, yalan, sahtecilik ve aldatma, kişisel sorunlar, mesleği yanlış temsil etme, gereksiz ısrarlara karşı tutum, çalışmasının sorumluluğunu alma başlıkları altında yer alan bir dizi standarttan oluşmaktadır.

e) Sosyal Hizmet Uzmanının Sosyal Hizmet Mesleğine Karşı Etik Sorumlulukları: Mesleğin bütünlüğü, değerlendirme ve araştırma başlikları altında yer alan bir dizi standarttan oluşmaktadır.

f) Sosyal Hizmet Uzmanının Sosyal Hizmet Topluma Karşı Etik Sorumluluklarn: Sosyal refah, toplum katılımı, toplumu etkilen acil durumlar, sosyal ve siyasi eylem başlıkları altında yer alan bir dizi standarttan oluşmaktadır (NASW, 2008).

\section{Sonuç}

Sosyal hizmet mesleği diğer tüm meslekler gibi bilgi, beceri ve değer temelleri üzerine inşa edilmiştir. Sosyal hizmet uzmanlarının etkili uygulamalar gerçekleştirebilmesi bilgi temelinin beceri temeli ile desteklenmesiyle mümkün olmaktadır. Beceri temeliyle doğrudan ilişkili olan yeterlilik kavramı ise mesleki rolü yerine getirebilme yeteneğini ifade etmektedir. Amerika Birleşik Devletleri özelinde gerçekleştirilen bu çalışmada; sağlık hizmetleri, madde kullanım bozukluğu olan müracaatçılar, çocuk refahı alanı, ergenlere yönelik sosyal hizmet uygulamaları, klinik sosyal hizmet uygulamaları, yaşlı yetişkine bakım veren aile üyelerine ilişkin uygulamalar ve okul sosyal hizmet uygulamaları bağlamında sosyal hizmet mesleğinin yeterlilik ve uygulama standartlarına işaret edilmiştir.

Sonuç olarak, sosyal hizmet uygulamalarında geniş bir yelpazede birçok durum ve farklı kaygıları olan müracaatçılarla çalışılması bütün durumlarla ilgili tek bir yeterlilik ve uygulama standarttı geliştirilemeyeceğini göstermektedir. Sosyal, politik ve ekonomik koşuların etkisiyle değişen durumlara 
ilişkin yeterlilik ve uygulama standartları da değişmektedir. Bu durumda ise yeni uygulama standartları belirlemeyi gerekli kılabilmektedir. Sosyal hizmet uygulamalarının gerçekleştiği koşulların sürekli değişmekte olmasına rağmen, mevcut şartlarda kültürel yeterlilikler ve etik değerlerin dikkate alınmasıyla uzlaşılarak oluşturulmuş standartların açıkça belirtilmesi, sosyal hizmet bilgi temelinin nasıl kullanılacağına, etkili mesleki uygulamaların nasıl yapılabileceğine, hizmet sunumunda kamu kurum ve kuruluşları ile gönüllü kuruluşlar arasında nasıl bir işbirliği yapılacağına ve sunulan hizmetlerin nasıl değerlendirilebileceğine ışık tutacaktır. Son olarak, bu çalışmanın Türkiye bağlamında yapılacak standart geliştirme çalışmalarına da yardımcı olacağı düşünülmektedir. 


\title{
EXTENDED ABSTRACT
}

\section{An Overview of the Social Work Practice Standards in the USA}

\author{
* \\ Ömer Faruk Cantekin - Ayşe Nur Pekasıl \\ Gazi University
}

The United States of America is a federal constitutional republic composed of 50 states and a federal region. In line with this, national and state-level organizations have developed different competency and practice standards using different reference frameworks, though some of standards overlap. The leading national organization in the USA is National Association of Social Workers - NASW. It is based in Washington and it has produced the most comprehensive documents concerning social work competency and practice standards. There are competency standards developed at the national level by NASW regarding the sub-fields of social work practices (such as clients with substance use disorders, the practice of social work with adolescents, and school social work practices). Similarly, there are competency standards developed by School Social Work Association of America SSWAA for school social work practices. In addition to the national standards, there are standards developed by universities, NGOs, and related councils in the states for social work education. The aim of this study is to portray a general profile of the competency and practice standards of social work as a profession in the United States of America. To this end, being the most comprehensive and commonly referred ones, the standards developed by National Association of Social Workers (NASW) have been briefly explained.

Firstly, social work services have an important place in healthcare. Social workers implement social work practices in a number of areas such as preventive public health, primary and acute care, rehabilitation, and long-term care. For such practices, NASW has developed social work standards in healthcare settings. These standards are categorized under these titles: ethics and values, qualifications, knowledge, cultural and linguistic competence, screening and assessment, care planning and intervention, advocacy, 
interdisciplinary and inter-organizational collaboration, practice evaluation and quality improvement, record keeping and confidentiality, workload sustainability, professional development, and supervision and leadership (NASW, 2016). In addition, NASW developed in 2013 social work practice standards for clients with substance use disorders grouped under 12 headings: ethics and values, qualifications, assessment, intervention, decision making and practice evaluation, record keeping, workload management, professional development, cultural competence, interdisciplinary leadership and collaboration, advocacy, collaboration (NASW, 2013). For child welfare, there are 14 standards under these titles: ethics and values, qualifications, knowledge, and practice requirements, professional development, advocacy, collaboration, record keeping and confidentiality of client information, cultural competence, assessment, intervention, family engagement, youth engagement, permanency planning, supervision, and administration (NASW, 2012). Another group of standards is about adolescent, which has 11 headings: knowledge of adolescent development, assessment, knowledge of family dynamics, cultural competence, self-empowerment of adolescents, understanding adolescents' needs, multidisciplinary case consultation, confidentiality, work environment, advocacy, policies for effective practice (NASW, 2003). For clinical social work practice, the standards are: ethics and values, specialized practice skills and interventions, referrals, accessibility to clients, privacy and confidentiality, supervision and consultation, professional environment and procedures, documentation, independent practice, cultural competence, professional development, and technology (NASW, 2005). Further, NASW issued in 2010 the practice standards for family caregivers of older adults, while it published the practice standards for school social work in 2012, under these titles: ethics and values, qualifications, assessment, intervention, decision making and practice evaluation, record keeping, workload management, professional development, cultural competence, interdisciplinary leadership and collaboration, and advocacy (NASW, 2012). Another important area of social work practice standards is cultural competence, for which NASW developed 10 standards and indicators in 2015, highlighting these points: ethics and values, selfawareness, cross-cultural knowledge, cross-cultural skills, service delivery, empowerment and advocacy, diverse workforce, professional education, language and communication, leadership to advance cultural competence 
(NASW, 2015). A final point to remember is that social workers need to implement social work practices in different settings according to the codes of ethics. Thus, Code of Ethics developed by NASW in 2008 accounts for a common framework of reference for the ethical practice (NASW, 2008).

All in all, social work, like other professions, is built upon knowledge, skills, and values. For social workers to implement effective practices, knowledge base need to be supported with skills development. A closely related concept with skills is competence, referring to the ability to fulfill the professional role. Social workers encounter a wide ranging cases and clients with different concerns, which implies the difficulty of developing one standard for all cases. The changes in social, political, and economic conditions bring about changes in different cases, which requires a change in competence and practice standards. Although the conditions of social work delivery are changing, to explicitly express the standards developed with a broad consensus considering the cultural competencies and ethical values in the current circumstances is thought to shed light on how the knowledge base of social work should be used, how effective professional practices should be implemented, what kind of collaboration could be possible between public and voluntary organizations in service delivery, and how the services provided could be evaluated. Finally, this study is expected to contribute to the standard development processes in social work in Turkey.

\section{Kaynakça / References}

National Association of Social Workers.(2003). Standards for the Practice of Social Work with Adolescents. Washington: NASW.

National Association of Social Workers.(2005). Standards for Clinical Social Work in Social Work Practice. Washington: NASW.

National Association of Social Workers.(2008). Code of Ethics . Washington: NASW.

National Association of Social Workers. (2010). Standards for Social Work Practice with Family Caregivers of Older Adults. Washington: NASW.

National Association of Social Workers.(2012). Standards for School Social Work Services. Washington: NASW.

National Association of Social Workers.(2013). Standards for Social Work Practice with Clients with Substance Use Disorders. Washington: NASW. 
National Association of Social Workers.(2013). Standards for Social Work Practice in Child Welfare Work Group. Washington: NASW.

National Association of Social Workers. (2015). Standards and Indicators for Cultural Competence in Social Work Practice. Washington: NASW.

National Association of Social Workers.(2016). Standards for Social Work Practice in Health Care Settings. Washington: NASW.

\section{Kaynakça Bilgisi / Citation Information}

Cantekin, Ö. F. ve Pekasıl, A. N. (2020). Sosyal hizmet mesleği uygulama standartlarına genel bakış: Amerika Birleşik Devletleri örneği. OPUS-Uluslararası Toplum Araştırmaları Dergisi, 15(23), 2231-2255. DOI: 10.26466/opus.650547 